\title{
The Effect of Tax Regulation Understanding, Justice Principles and Tax Sanction towards the Tax Payer Compliance
}

Deanty Kurnia Novelasari, Wiwik Utami

Mercu Buana University Jakarta

DOI: $10.36348 / \mathrm{sb} .2020 . \mathrm{v} 06 \mathrm{i} 02.002$

| Received: 18.02.2020 | Accepted: 26.02.2020 | Published: 29.02.2020

*Corresponding author: Deanty Kurnia Novelasari

\section{Abstract}

The objective of this research is to analyze and find out the effect of tax regulation understanding, justice principles and tax sanction towards the tax payer compliance. This research is done in UMKM located in Tanah Abang Market area. The data is collected by distributing questionnaires. Analysis method used in this research is the random sampling. This research has the population of 3.870 and is counted by the slovin formula that obtains 97.48 samples. However, the researcher has determined the sample to be 100 respondents. The result of this research shows that the tax regulation understanding and the justice principles do not have positive effects towards the tax payer's compliance while the tax sanction had a positive effect towards the tax payer's compliance.

Keywords: Tax, Regulation Understanding, Tax Sanction, Tax Payer Compliance.

Copyright @ 2020: This is an open-access article distributed under the terms of the Creative Commons Attribution license which permits unrestricted use, distribution, and reproduction in any medium for non-commercial use (NonCommercial, or CC-BY-NC) provided the original author and source are credited.

\section{INTRODUCTION}

The Micro, Small and Middle Businesses have a significant role towards the economic sector in Indonesia. The Ministry of Cooperatives and SMEs publishes the contribution of MSMEs reaching more than $60 \%$ of GDP (Gross Domestic Products). The ability of UMKM in supporting economy in Indonesia has been proven during the monetary crisis in 1997 until 1998. Based on the BPS data year 1998, in 4 years period since 1993, approximately, more than $99 \%$ of businessmen were those who ran UMKM (small scale industries).

The launch of Government Regulation No.23 of 2018 by the government broke down people's opinions about a complicated and troublesome tax system.

On Saturday, $26^{\text {th }}$ of June 2018, The Ministry of Finance Sri Mulyani Indrawati assisted President Joko Widodo in doing the socialization on the Final UMKM income tax (PPh) 0, 5\% in Sanur Paradise, Prime Plaza Hotel Bali. The event that was attended by 1.000 UMKM businessmen aimed to continue the sharing of information on the decrease of the tariff of $\mathrm{PPh}$ Final UMKM from $1 \%$ to $0,5 \%$ based on the
Government Regulation Number 23 Year 2018 that was launched a day before by Jokowi in Surabaya.

"This policy is taken by the Government in considering that the business sector has developed well in the last few years. In this industrial revolution 4.0, the government should involve in the development of business sector, especially Micro, Small, and Middle Businesses. In observing how dynamic this business world is, the government gives the incentive by decreasing the tariff of Final UMKM income tax (PPh) from $1 \%$ to be $0.5 \%$," said Sri Mulyani as quoted from her official Facebook account, Sunday $\left(24^{\text {th }}\right.$ of June, 2018).

The Government Regulation Number 23 Year 2018 that is effective per $1^{\text {st }}$ July of 2018 . The government hopes that the contribution of MSMEs to the country's economy will increase more.

The percentages found by Schneider \& Enste that Indonesia's underground economy averaged $19.9 \%$ from 2002-2007 of GDP. This can be interpreted that the level of taxpayer compliance in Indonesia is still low. 
Based on the problems that have been described above, the purpose of this study is to analyze and understand the understanding of taxation rules, the principle of fairness and tax sanctions that have positive or negative effects on tax compliance for SMEs in the Tanah Abang Market area.

\section{LITERATURE REVIEW Theory of Planned Behaviour}

Theory of Reasoned Action (TRA) was developed by Ajzen and named as Theory of Planned Behaviour (TPB). According to [1], the target individual has a big chance to adopt a behavior if he/she has a positive attitude towards the behavior, get approval from the other individual who is close to him/her and who is also related with it and believes that the behavior may be done well.

Theory of Reasoned Action has 2 featurs, one of them is that the control of behavior perspective has an implication on the interest. In this research, in the variable of tax regulation understanding, the tax payers should have curiosity and motivation that encourage them to know and understand about the tax regulation that is valid.

\section{Theory of Justice}

Theory of Aristoteles that is emphasized on the balance and proportion. Aristoteles divided the justice into distributive and commutative justices.

The justice principle variable in this research fits with the theory of Aristoteles on distributive justice, in which the tasks from the government to its citizens to determine what may be demanded by them in their country. The construction obliges the law maker to pay more attention in formulating the justice concepts into a law.

\section{Compliance Theory}

Tyler said that there are two perspectives in the sociology literature on tax compliance, namely instrumental and normative. The indicator of the level of tax payer compliance may be known by seeing whether the tax payer has submitted their tax return or not.

The tax sanction that is determined by the Government through Law and Regulation is one of efforts to make the tax payer comply it.

\section{The Tax Regulation Understanding towards the Tax Payer Compliance}

An increased level of knowledge and understanding of tax regulations will encourage taxpayers to pay taxes. A research done by Fauzi Kertahadi Mirza showed that the tax regulation understanding partially gives significant effect towards the Tax Payer compliance.

H1: Tax regulation Understanding gives positive effect towards the tax payer's compliance

\section{The Justice Principles towards the Tax Payers Compliance}

Vogel, Spicer, dan Becker described that the tax payer tends to avoid paying the tax if they consider that the tax system is unfair.

A research by Fauzi Kertahadi Mirza [2] showed that the justice principle partially give significant effect towards the Tax Payer compliance.

$\mathrm{H} 2$ : The justice principle gives positive effect towards the tax payer compliance.

\section{The Tax Sanction towards the Tax Payer Compliance}

The tax payer will comply their tax obligation if they think that the tax sanction is not beneficial. Supported by a former research done by Muliary and Ery [3], in which the result showed that the perception on tax sanction gives positive effect towards the tax payer reporting compliance. H3: Tax Sanction give positive effect toward the tax payer compliance

\section{Design and method of research}

This research is causal research with primary data. The number of population is 3.870 and the sample is 100 respondents which are counted by slovin formula. The sampling technique in this research is random sampling. The test tool used is smartPLS 3.0.

\section{RESULT AND DISCUSSION Description of Tax Regulation Understanding}

In a whole, among 5 (five) indicator variables of tax regulation understanding, the mean value that affects tax payer compliance is 4 indicators by the statement: I know and understand about the tax function as an $\mathrm{n}$ indicator to manage and implement the obligation in economic and social sectors" with the score of 3,65 . So, it means that people who have UMKM understand that one of the tax functions is as an indicator to manage and implement their obligation in the economic and social sectors by the tax system in Indonesia.

\begin{tabular}{|l|c|}
\hline \multicolumn{1}{|c|}{ Indicator } & Mean \\
\hline General provision and procedures of tax & 3.45 \\
\hline $\begin{array}{l}\text { Tax system } \\
\text { (Self Assessment) }\end{array}$ & 3.39 \\
\hline Tax Function & 3.61 \\
\hline Tax Function & 3.65 \\
\hline Tax Function & 3.38 \\
\hline
\end{tabular}




\section{Description of Justice Principle Variable}

In a whole, among 4 (four) indicators of justice principle variable, mean value that affects the tax payer compliance is 3 with a statement "I feel that paying taxes is too much compared to the benefit I receive"" with the score 3,76 . Thus, it means that people who have UMKM feel that the benefit they receive is not worth with the tax value that they pay to the Nation.

\begin{tabular}{|l|c|}
\hline \multicolumn{1}{|c|}{ Indicator } & Mean \\
\hline $\begin{array}{l}\text { Tax system in Indonesia is } \\
\text { managed fairly }\end{array}$ & 3.64 \\
\hline $\begin{array}{l}\text { Benefit value received is in } \\
\text { accordance with and fair as } \\
\text { the tax paid Nilai }\end{array}$ & 3.52 \\
\hline $\begin{array}{l}\text { Benefit value received is in } \\
\text { accordance with and fair as } \\
\text { the tax paid Nilai }\end{array}$ & 3.76 \\
\hline $\begin{array}{l}\text { Imposition of flat tax tariff is } \\
\text { fair }\end{array}$ & 3.44 \\
\hline
\end{tabular}

\section{Description of Tax Sanction}

In a whole, among 5 (five) statements in tax sanction variable, the mean value that affects tax payer compliance is the statement: The Tax Sanction is heavier than the violation" with the score 3,60 , which means that people who have UMKM have an opinion that the sanction is heavier than the violation.

\begin{tabular}{|l|c|}
\hline \multicolumn{1}{|c|}{ Indicator } & Mean \\
\hline Tax sanction imposed to tax regulation breaker is heavy & 3.60 \\
\hline Heavy sanction is a way to educate tax payers. & 3.47 \\
\hline Heavy sanction is a way to educate tax payers. & 3.44 \\
\hline Tax sanction should be given to its breakers without any tolerance & 3.51 \\
\hline Tax sanction should be given to its breakers without any tolerance & 3.58 \\
\hline
\end{tabular}

\section{Covergent Validity of Tax Regulation Understanding} Variable (X1)

Tax regulation understanding variable among those 5 indicators, all of loading factor scores is above
0,7 which means that there is no indicator eliminated from the data processing.

\begin{tabular}{|l|c|}
\hline \multicolumn{1}{|c|}{ Indicator } & loading factor \\
\hline General provision and procedures of tax & 0,83 \\
\hline Tax system & \\
(Self Assessment) & 0,79 \\
\hline Tax Function & 0,73 \\
\hline Tax Function & 0,75 \\
\hline Tax Function & 0,79 \\
\hline
\end{tabular}

\section{Covergent Validity of Justice Principle Variable (X2)}

In justice principle variable, among 4 indicators, there are 3 indicators that have loading factor value above 0.7 , and 1 indicator has score between $0,5-06$ which means that there is no indicator eliminated in data processing and they are considered as sufficient [4].

\begin{tabular}{|l|c|}
\hline \multicolumn{1}{|c|}{ Indicator } & loading factor \\
\hline Tax system in Indonesia is managed fairly & 0,78 \\
\hline Benefit value received is in accordance with and fair as the tax paidNilai & 0,82 \\
\hline Benefit value received is in accordance with and fair as the tax paidNilai & 0,65 \\
\hline Imposition of flat tax tariff is fair & 0,76 \\
\hline
\end{tabular}

\section{Covergent Validity of Tax Sanction Variable (X3)}

Among 5 indicators of tax sanction variable, 4 indicators have loading factor score above 0,7 and 1 indicator has score of $0,5-06$ which means that there is no indicator eliminated in data processing and they are considered as sufficient [4]. 


\begin{tabular}{|l|c|}
\hline \multicolumn{1}{|c|}{ Indicator } & loading factor \\
\hline Tax sanction imposed to tax regulation breakers is heavy & 0,77 \\
\hline Imposition of heavy sanction is a way to educate tax payers. & 0,76 \\
\hline Imposition of heavy sanction is a way to educate tax payers. & 0,68 \\
\hline Tax sanction should be given to its breakers without any tolerance & 0,83 \\
\hline Tax sanction should be given to its breakers without any tolerance & 0,82 \\
\hline
\end{tabular}

\section{Covergent Validity of Tax Payer Compliance} Variable (Y)

Among 5 indicators of tax regulation understanding variable, all of loading factor score is above 0,7 which means that there is no indicator eliminated in data processing.

\begin{tabular}{|l|c|}
\hline \multicolumn{1}{|c|}{ Indicator } & loading factor \\
\hline Tax Payer compliance in self registration & 0,76 \\
\hline Tax Payer compliance in counting Taxes k & 0,80 \\
\hline The compliance of Tax Payer in paying taxes & 0,81 \\
\hline The compliance of Tax Payers in filling and reporting Tax Return (SPT) & 0,78 \\
\hline The compliance of Tax Payers in filling and reporting Tax Return (SPT) & 0,78 \\
\hline
\end{tabular}

Covergent validity may also be known through Average Variance Extracted (AVE). An instrument is said to be fulfilling Covergent validity test if it has
Average Variance Extracted ( $A V E$ ) above 0,5 and all variables in this research have $A V E$ score above 0,5

Average Variance Extracted (AVE)

\begin{tabular}{|l|c|}
\hline \multicolumn{1}{|c|}{ Variabel } & Average Variance Extracted (AVE) \\
\hline Tax Regulation Understading (X1) & 0,61 \\
\hline Justice Principle (X2) & 0,57 \\
\hline Tax Sanction (X3) & 0,60 \\
\hline Tax Payer Compliance (Y) & 0,62 \\
\hline
\end{tabular}

\section{Discriminant Validity of Tax Regulation}

\section{Understanding Variable (X1)}

Indicators in variable of tax regulation understanding have represented it dimension better than other dimensions, as seen from the loading score towards its dimension that is higher than loading score towards other dimensions.

\begin{tabular}{|l|c|c|}
\hline \multicolumn{1}{|c|}{ Indicator } & $\begin{array}{c}\text { Loading Score towards } \\
\text { its Dimension }\end{array}$ & $\begin{array}{c}\text { Highest Loading Score towards } \\
\text { other Dimensions }\end{array}$ \\
\hline General provision and procedures of tax & 0,83 & 0,68 \\
\hline Tax System (Self Assessment) & 0,80 & 0,69 \\
\hline Tax Function & 0,73 & 0,58 \\
\hline Tax Function & 0,75 & 0,59 \\
\hline Tax Function & 0,80 & 0,69 \\
\hline
\end{tabular}

\section{Discriminant Validity of Justice Principle Variable} (X2)

The indicator of justice principle variable has represented its dimension better than other dimensions, as seen by the loading score towards its dimension that is higher than the loading score towards other dimensions.

\begin{tabular}{|l|c|c|}
\hline \multicolumn{1}{|c|}{ Indicator } & $\begin{array}{c}\text { Loading Score } \\
\text { towards its Dimension }\end{array}$ & $\begin{array}{c}\text { Highest Loading Score } \\
\text { towards other Dimensions }\end{array}$ \\
\hline Tax system in Indonesia is managed fairly & 0,78 & 0,71 \\
\hline $\begin{array}{l}\text { Benefit value received is not in accordance with } \\
\text { and fair as the tax paid }\end{array}$ & 0,82 & 0,65 \\
\hline $\begin{array}{l}\text { Benefit value received is not in accordance with } \\
\text { and fair as the tax paid }\end{array}$ & 0,66 & 0,57 \\
\hline Imposition of flat tax tariff is fair & 0,77 & 0,66 \\
\hline
\end{tabular}


Deanty Kurnia Novelasari \& Wiwik Utami., Sch Bull, Feb 2020; 6(2): 46-52

Discriminant Validity of Tax Sanction Variable (X3)

The indicator in tax sanction variable has represented its dimension better than other dimensions, as seen by the loading score towards its dimension that is higher than towars the other dimensions.

\begin{tabular}{|l|c|c|}
\hline \multicolumn{1}{|c|}{ Indicator } & $\begin{array}{c}\text { Loading Score } \\
\text { towards its Dimension }\end{array}$ & $\begin{array}{c}\text { Highest Loading Score } \\
\text { towards other Dimensions }\end{array}$ \\
\hline Tax Sanction imposed to tax regulation breakers is heavy & 0,77 & 0,66 \\
\hline Imposition of heavy sanction is a way to educate tax payers. & 0,76 & 0,62 \\
\hline Imposition of heavy sanction is a way to educate tax payers. & 0,68 & 0,63 \\
\hline $\begin{array}{l}\text { Tax sanction should be given to its breakers without any } \\
\text { tolerance }\end{array}$ & 0,83 & 0,67 \\
\hline $\begin{array}{l}\text { Tax sanction should be given to its breakers without any } \\
\text { tolerance }\end{array}$ & 0,83 & 0,67 \\
\hline
\end{tabular}

Discriminant Validity of Tax Payer Compliance (Y)

The indicator of tax payer compliance variable has represented its dimension better than other dimensions, as observed that in the loading score towards its dimension is higher than loading score towards other dimensions.

\begin{tabular}{|l|c|c|}
\hline \multicolumn{1}{|c|}{ Indicator } & $\begin{array}{c}\text { Loading Score towards its } \\
\text { Dimension }\end{array}$ & $\begin{array}{c}\text { Highest Loading Score } \\
\text { towards other Dimensions }\end{array}$ \\
\hline Tax Payer compliance in self registration & 0,77 & 0,51 \\
\hline Tax Payer compliance in Calculating Taxes & 0,81 & 0,47 \\
\hline Tax Payer Compliance in Paying Taxes & 0,81 & 0,53 \\
\hline $\begin{array}{l}\text { Tax Payer Compliance in Fulfilling and } \\
\text { Reporting Tax Return }\end{array}$ & 0,78 & 0,61 \\
\hline $\begin{array}{l}\text { Tax Payer Compliance in Fulfilling and } \\
\text { Reporting Tax Return }\end{array}$ & 0,78 & 0,46 \\
\hline
\end{tabular}

\section{Composite Reliability}

All variables in this research have cronbachs alpha above 0,7 , which means that those variables are reliable.

Scores of Composite Reliability and Cronbachs Alpha

\begin{tabular}{|l|c|c|}
\hline \multicolumn{1}{|c|}{ Variable } & Composite Reliability & Cronbachs Alpha \\
\hline Tax Regulation Understanding (X1) & 0,88 & 0,84 \\
\hline Justice Principle (X2) & 0,84 & 0,75 \\
\hline Tax Sanction (X3) & 0,88 & 0,83 \\
\hline Tax Payer Compliance (Y) & 0,89 & 0,84 \\
\hline
\end{tabular}

\section{Coefficient Determinant Test $\left(\mathbf{R}^{2}\right)$}

In this research, there is a coefficient score of 0,46 , which means that variable of Tax Regulation
Understanding, Justice Principles, and Tax Sanction are limited in explaning the Tax Payer Compliance variable with the percentage of $46 \%$.

\section{R-Square Score}

\begin{tabular}{|l|c|c|}
\hline & R Square & R Square Adj. \\
\hline $\begin{array}{l}\text { Tax Payer } \\
\text { Compliance }\end{array}$ & 0,46 & 0,44 \\
\hline
\end{tabular}

\section{Hypothesis Test}

This research shows that the connection between Tax Regulation Understanding and Tax Payer Compliance and between Justice Principles and Tax Payer Compliance do not give positive effect in which each variable has scores of $\mathrm{T}_{\text {statistik }}$ of $1,658\left(\mathrm{~T}_{\text {statistik }}<\right.$
1,96) and $\mathrm{T}_{\text {statistik }}$ of $1,074\left(\mathrm{~T}_{\text {statistik }}<1,96\right)$. Therefore, the hypothesis of $\mathrm{H}_{1}$ and $\mathrm{H}_{2}$ in this research is denied.

Meanwhile, the association between Tax Sanction and Tax Payer Compliance gives positive effect in which the scores of $\mathrm{T}_{\text {statistik }}$ is $2,177\left(\mathrm{~T}_{\text {statistik }}>1\right.$, 96). Thus, $\mathrm{H}_{3}$ hypothesis in this research is accepted. 
The Resulf of Path Coefficient Hypothesis (STDEV, T-Values)

\begin{tabular}{|l|c|c|c|}
\hline & STDEV & T Statistik & P Value \\
\hline $\begin{array}{l}\text { Tax Regulation } \\
\text { Understanding (X1) - Tax } \\
\text { Payer Compliance (Y) }\end{array}$ & 0,155 & 1,658 & $\mathbf{0 , 0 9 8}$ \\
\hline $\begin{array}{l}\text { Justice Principles (X2) - } \\
\text { Tax Payer Compliance (Y) }\end{array}$ & 0,151 & 1,074 & $\mathbf{0 , 2 8 3}$ \\
\hline $\begin{array}{l}\text { Tax Sanction (X3) - Tax } \\
\text { Payer Compliance (Y) }\end{array}$ & 0,139 & 2,177 & $\mathbf{0 , 0 3 0}$ \\
\hline
\end{tabular}

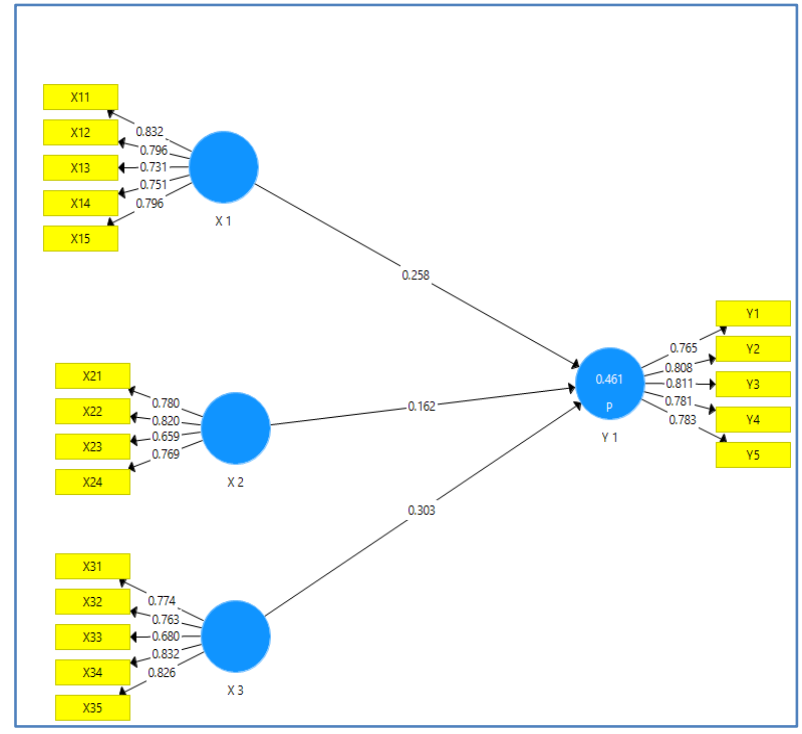

Fig-1: Algorithm

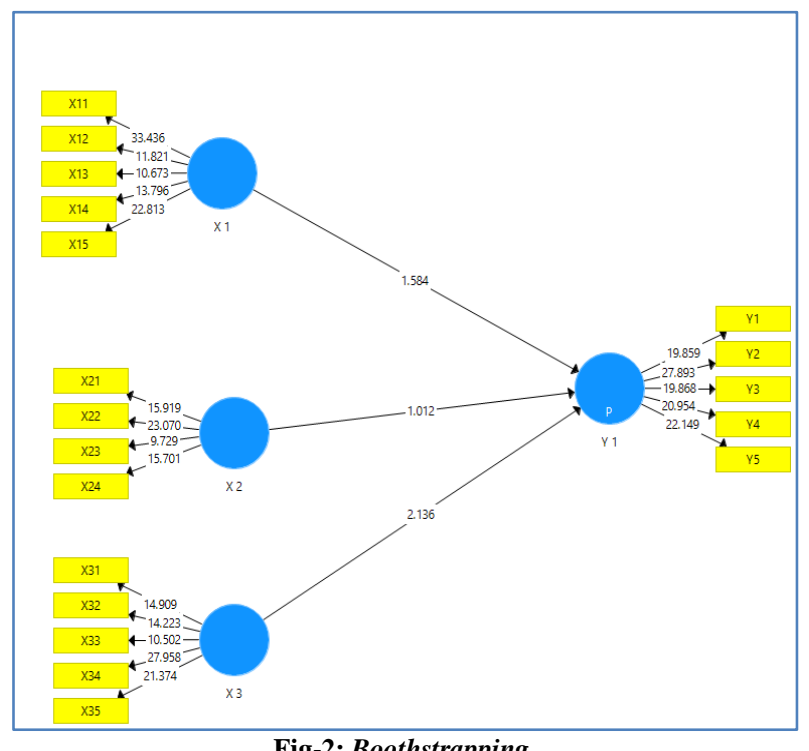

Fig-2: Boothstrapping

\section{DISCUSSION}

\section{Tax Regulation Understanding}

Tax regulation understanding does not give a positive effect towards tax payer compliance. It is not in line with theory of planned behavioral which assumed that control of perception of attitude has an implication on motivation towards interest.
One of factors that causes tax regulation understanding has no positive effect is because the regulations issued by Directorate General of Taxes have not been understood well during the implementation of tax calculation and reporting. The tax regulation is complicated and it cannot be understood easily by the community. It also often changes without any notification or direct socialization to Tax payers.

Meanwhile, the other factor may be because of the less interest or motivation of the tax payers to search or update tax regulations especially those related to them.

\section{Justice Principles}

The justice principle gives no positive effect towards tax payer compliance. It contradicts Aristoteles concept on distributive justice which described that justice demands every individual to get his rights, so that it is proportional.

\section{Tax Sanction}

Tax Sanction give positive effect towards tax payer compliance. It may be said that the tax sanction determined by the Directorate General of Taxses namely administrative sanction or law penalty encourages the tax payer compliance effectively.

\section{CONCLUSION}

- Tax Regulation Understanding gives no positive effect towards the tax payer compliance. It is because of the changeable tax law and regulation without any notification or socialization by Directorate General of Taxes to tax payer. They have not been shared to all areas.

- Justice Principle has no positive effect towards tax payer compliance. The reason is because tax payers have not been satisfied and have not felt the justice given by the Government through facilities or other factors.

- Tax Sanction gives positive effect towards the tax payer compliance. Basically, the sanction is aimed to make the tax payer comply in fulfilling their tax obligation. It is expected that through the explicit sanction, the tax payer will obey the tax regulation and, consequently, the tax acceptance will be increased. 


\section{SUGGESTION}

- It is necessary for the Directorate General of Taxes to do socialization regulary and with wider scope. Thus, there will be no more tax payer who does not understand about tax regulation and they may understand the implementation. Surely, it will improve the tax payer compliance in the implementation of their tax obligation.

- Government should assure the equality in providing public facilities that may be used directly by the community. It means that the facility is not only provided in some areas but all. The government should also be fair in determining the tax tariff for all tax payers.

- The government should do some improvement in holding the law consistently related with the tax sanction based on the law and regulations.

\section{REFFERENCE}

1. Dharmawan, F. (2012). Pengaruh Keadilan Pajak terhadap Tingkat Kepatuhan Wajib Pajak Pribadi (Studi pada KPP Pratama Malang Selatan). Jurnal Ilmiah Mahasiswa FEB, 1(1).

2. Mustofa, F. A. (2016). Pengaruh pemahaman peraturan perpajakan, tarif pajak dan asas keadilan terhadap kepatuhan wajib pajak (Studi pada Wajib Pajak Usaha Mikro Kecil dan Menengah yang Berada Di Wilayah Kerja Kantor Pelayanan Pajak Pratama Batu Setelah Diberlakukannya Peratu. Jurnal Mahasiswa Perpajakan, 8(1).

3. Nuwal, P., Dixit, R., Dargar, P., \& George, J. (2012). Pleural effusion as the initial manifestation of chronic myeloid leukemia: Report of a case with clinical and cytologic correlation. Journal of Cytology/Indian Academy of Cytologists, 29(2), 152.

4. Ghozali, I. (2006). Aplikasi analisis multivariate dengan program SPSS. 